\title{
Hubungan antara Umur dan Paritas dengan Kejadian Hiperemesis Gravidarum Pada Ibu Hamil
}

Leny

Akademi Kebidanan Budi Mulia Palembang

Informasi Artikel :

Diterima : 20 November 2020

Direvisi : 23 Novembe 2020

Disetujui : 03 Desember 2020

*Korespondensi Penulis : basorirayca@gmail.com

\begin{abstract}
A B S T R A K
Hiperemesis gravidarum adalah muntah yang terjadi sampai umur kehamilan 20 minggu. Hiperemesis gravidarum dapat terjadi hampir pada 50\% kasus ibu hamil dan terbanyak pada usia kehamilan 6-12 minggu. Tujuan penelitian ini adalah untuk mengetahui hubungan antara umur dan paritas dengan kejadian Hiperemesis Gravidarum pada ibu hamil di Klinik Budi Mulia Medika Palembang Tahun 2020. Penelitian ini menggunakan metode survei analitik dengan pendekatan Cross Sectional. Populasi penelitian ini adalah seluruh ibu hamil yang datang berkunjung di klinik Budi Mulia Medika pada bulan JanuariOktober 2020 yang berjumlah 118 responden. Sampel penelitian ini diambil secara non random sampling dengan sampel penelitian adalah total populasi yaitu seluruh ibu hamil yang datang berkunjung di klnik Budi Mulia Medika pada bulan Januari-Oktober 2020. Data yang diperoleh menggunakan analisis univariat dan analisis bivariat menggunakan uji statistik Chi-square. Dari hasil uji Chi square menunjukkan ada hubungan yang bermakna antara umur dengan kejadian Hiperemesis Gravidarum dengan p.value $=0,001$ dan ada hubungan yang bermakna antara paritas dengan kejadian Hiperemesis Gravidarum dengan p.value $=0,001$ di Klinik Budi Mulia Medika Palembang tahun 2020. Dari hasil penelitian ini, menyarankan agar peneliti yang akan datang dapat menambah variabel yang di teliti yang mempengaruhi kejadian hiperemesis Gravidarum.
\end{abstract}

Kata Kunci : Hiperemesis Gravidarum, umur, paritas

\section{ABSTRACT}

Hyperemesis gravidarum is vomiting that occurs until 20 weeks of gestation. Hyperemesis gravidarum can occur in almost $50 \%$ of cases of pregnant women and mostly at 6-12 weeks of gestation. The purpose of this study was to determine the relationship between age and parity with the incidence of hyperemesis gravidarum in pregnant women at the Budi Mulia Medika Clinic, Palembang in 2020. This study used an analytical survey method with a cross sectional approach. The population of this study were all pregnant women who came to visit the Budi Mulia Medika clinic in January-October 2020, totaling 118 respondents. The sample of this study was taken by nonrandom sampling, with the research sample being the total population, namely all pregnant women who came to visit the Budi Mulia Medika clinic in January-October 2020. The data were obtained using univariate analysis and bivariate analysis using the Chi-square statistical test.. The results of the Chi square test show that there is a significant relationship between age and the incidence of hyperemesis gravidarum with p.value $=0.001$ and there is a significant relationship between parity and the incidence of hyperemesis gravidarum with p.value $=0.001$ at the Budi Mulia Medika Clinic, Palembang in 2020. From the results This study suggests that future researchers can add to the variables studied that affect the incidence of Gravidarum hyperemesis.

Keywords: Hyperemesis Gravidarum, age, parity 


\section{PENDAHULUAN}

Hiperemesis gravidarum adalah muntah yang terjadi sampai umur kehamilan 20 minggu. Muntah begitu hebat dimana segala apa yang dimakan dan diminum dimuntahkan sehingga mempengaruhi keadaan umum dan pekerjaan sehari-hari, berat badan menurun dan dehidrasi (Nugraha, 2010).

Menurut World Health Organization (WHO), setiap tahun sekitar 20-50\% kematian wanita usia subur disebabkan hal yang berkaitan dengan kehamilan. Di negara berkembang diperkirakan 500 orang perempuan meninggal dunia akibat kehamilan dan persalinan (Himapid, 2009).

Di Indonesia angka kematian ibu merupakan angka tertinggi di ASEAN, jumlah kematian ibu sekitar 500.000 persalinan hidup sedangkan jumlah kematian perinatal sekitar 100.000 orang. Seandainya seorang ibu hanya mempunyai anak 3 orang saja maka Angka Kematian Ibu (AKI) dapat diturunkan menjadi 300.000 orang, sedangkan Angka Kematian Perinatal (AKP) menjadi 5.600.000 orang dalam persalinan hidup (Manuaba, 2008).

Penyebab langsung kematian ibu 90\% pada persalinan pada umumnya disebabkan karena komplikasi langsung pada kehamilan kematian ibu adalah perdarahan 28\%, eklampsia 24\%, infeksi $11 \%$, komplikasi puerperium $11 \%$, abortus $5 \%$, trauma obstetri $5 \%$, partus lama atau macet 5\%, serta lainnya $11 \%$. Penyebab tidak langsung kematian maternal adalah rendahnya status gizi, rendahnya status kesehatan serta adanya faktor resiko kehamilan pada ibu. Data menunjukkan bahwa $34 \%$ ibu hamil mengalami kurang energi kronis, sedangkan $40 \%$ menderita anemia gizi besi $22,4 \%$ ibu masih dalam keadaan terlalu "4 terlalu" yaitu $41 \%$ kehamilan terjadi pada ibu berumur kurang dari 18 tahun (terlalu muda), 3,8\% terjadi pada ibu berumur lebih dari 34 tahun (terlalu tua), 5,2\% persalinan terjadi pada interval waktu kurang dari 2 tahun (terlalu sering), 9,3\% ibu hamil mempunyai paritas lebih dari 3 (terlalu banyak) (Anwar, 2005).

Hasil pengumpulan data tingkat pusat Subdirektorat kebidanan dan kandungan Subdirektorat Kesehatan Keluarga dari 325 kota menunjukkan bahwa persentase ibu hamil resiko tinggi dengan hiperemesis gravidarum berat yang dirujuk dan mendapatkan pelayanan kesehatan lebih lanjut sebesar 20,44\%. Provinsi dengan persentase tertinggi adalah Sulawesi Tengah $(96,53 \%)$ dan di Yogyakarta $(76,60 \%)$ sedangkan yang terendah adalah provinsi Maluku Utara $(3,66 \%)$ dan Sumatera Selatan $(3,81 \%)$ (Profil Kesehatan Indonesia, 2008).

Berdasarkan data Provinsi Sumatera Selatan tahun 2008 terdapat angka kematian ibu (AKI) sebanyak 467 per 100.000 kelahiran hidup, sedangkan data nasional terdapat angkat kematian ibu (AKI) sebanyak 307 per 100.000 kelahiran hidup terbukti dari data diatas angka kematian ibu (AKI) Sumatera Selatan masih tinggi daripada angka kematian ibu (AKI) nasional. Penyebab angka kematian ibu (AKI) Sumatera pada tahun 2008 adalah eklampsi ada 2 orang (13,3\%), perdarahan ada 3 orang $(20 \%)$ dan lain-lain 3 orang (13,3\%) (Depkes, 2008).

Hiperemesis gravidarum dapat terjadi hampir pada 50\% kasus ibu hamil dan terbanyak pada usia kehamilan 6-12 minggu, kebanyakan perempuan mampu mempertahankan kebutuhan cairan dan nutrisi dengan diet dan akan teratasi hingga akhir trimester pertama. Penyebab penyakit ini masih belum diketahui secara pasti, tapi erat hubungannya dengan faktor psikologis (Prawirohardjo, 2009).

Peranan bidan dalam menurunkan angka kejadian kasus hiperemesis gavidarum antara lain salah satunya dengan memberikan pengawasan antenatal yaitu pencegahan dengan memberikan informasi dan edukasi tentang kehamilan kepada ibu-ibu, dengan maksud menghilangkan faktor psikis rasa takut (Manuaba, 2008).

Berdasarkan uraian di atas, maka peneliti tertarik untuk meneliti "Hubungan Umur dan paritas ibu Hamil dengan Kejadian Hiperemesis Gravidarum Pada Ibu Hamil di Klinik Budi Mulia Medika Palembang Tahun 2020”.

\section{METODE PENELITIAN}

Jenis penelitian ini menggunakan metode survei analitik dengan menggunakan pendekatan "Cross Sectional" dimana variabel umur ibu dan paritas serta variabel hiperemesis gravidarum akan dikumpulkan dalam waktu yang bersamaan (Notoatmodjo, 2005). Populasi adalah keseluruhan objek penelitian atau objek yang diteliti (Notoatmodjo, 2010). Populasi dan sampel dalam penelitian ini adalah semua ibu hamil trimester I dan trimester II yang datang berkunjung di klinik Budi Mulia Medika pada bulan September 2020.

HASIL PENELITIAN.

1. Penyajian Data

a. Analisis Univariat

Kejadian Hiperemesis Gravidarum 
Jurnal Kebidanan :Jurnal Medical Science Ilmu Kesehatan Akademi Kebidanan Budi Mulia Palembang Volume.10 No.2, Desember 2020

Variabel kejadian Hiperemesis Gravidarum dibagi menjadi 2 kategori yaitu ya bila terdiagnosa hiperemesis gravidarum dan tidak bila bukan/selain terdiagnosa hiperemesis gravidarum untuk lebih jelasnya dapat dilihat pada tabel 1 .

Tabel 1. Distribusi Frekuensi Responden Berdasarkan Kejadian Hiperemesis Gravidarum pada Ibu Hamil di Klinik Budi Mulia Medika Palembang Tahun 2020

\begin{tabular}{clcc}
\hline No & $\begin{array}{c}\text { Kejadian } \\
\text { Disminore }\end{array}$ & Frekuensi & Persentase \\
\hline 1. & Ya & 46 & $38,9 \%$ \\
\hline 2. & Tidak & 72 & $61,1 \%$ \\
\hline & Jumlah & $\mathbf{1 1 8}$ & $\mathbf{1 0 0}$ \\
\hline
\end{tabular}

Berdasarkan tabel 1 di atas kejadian hiperemesis gravidarum sebanyak 46 responden $(38,9 \%)$ dan tidak hiperemesis gravidarum sebanyak 72 responden $(61,1 \%)$.

\section{Umur}

Umur dibagi menjadi 2 kategori yaitu Resiko tinggi bila umur ibu $<20$ tahun atau $>35$ tahun dan resiko rendah Bila umur ibu 20-35 tahun untuk lebih jelasnya dapat dilihat pada Tabel 2.

Tabel 2. Distribusi Frekuensi Berdasarkan Umur di Klinik Budi Mulia Medika Palembang Tahun 2020

\begin{tabular}{cccc}
\hline No & Umur & Frekuensi & Persentase \\
\hline 1. & $\begin{array}{l}\text { Resiko } \\
\text { tinggi }\end{array}$ & 68 & $57,6 \%$ \\
\hline 2. & $\begin{array}{l}\text { Resiko } \\
\text { rendah }\end{array}$ & 50 & $42,4 \%$ \\
\hline & Jumlah & $\mathbf{1 1 8}$ & $\mathbf{1 0 0}$ \\
\hline
\end{tabular}

Berdasarkan tabel 2 diatas responden dengan umur resiko tinggi sebanyak 68 responden $(57,6 \%)$ dan responden dengan umur resiko rendah sebanyak 50 responden $(42,4 \%)$.

\section{Paritas}

Paritas di bagi menjadi 2 kategori yaitu paritas resiko tinggi bila paritas ibu 1 dan $>3$ anak dan paritas resiko rendah bila paritas ibu 2-3 anak jelasnya dapat dilihat pada tabel 3 .
Tabel 3 Distribusi Frekuensi Berdasarkan Paritas di Klinik Budi Mulia Medika Palembang Tahun 2020

\begin{tabular}{cccc}
\hline No & Paritas & Frekuensi & Persentase \\
\hline 1. & Resiko tinggi & 57 & 48,3 \\
\hline 2. & Resiko rendah & 61 & 51,7 \\
\hline & Jumlah & $\mathbf{1 1 8}$ & $\mathbf{1 0 0}$ \\
\hline
\end{tabular}

Berdasarkan tabel 3 responden dengan paritas resiko tinggi sebanyak 57 responden $(48,3 \%)$ dan responden dengan paritas resiko rendah sebanyak 61 responden $(51,7 \%)$.

b. Analisis Bivariat

Hubungan antara Umur dengan Kejadian Hiperemesis Gravidarm Pada Ibu Hamil

Dilakukan Uji Statistik bivariat antara variabel dependen (kejadian Hiperemesi Gravidarum) dengan variabel independen (umur). Hasil uji statistik dapat dilihat pada tabel 4 di bawah ini.

Tabe1 4. Hubungan Antara Umur dengan Kejadian Hiperemesis Gravidarum pada ibu Hamil di Klinik Budi Mulia Medika Palembang Tahun 2020

\begin{tabular}{|c|c|c|c|c|c|c|}
\hline \multirow[t]{3}{*}{ No } & \multirow[t]{3}{*}{ Umur } & \multicolumn{3}{|c|}{$\begin{array}{c}\text { Kejadian } \\
\text { Hiperemesis } \\
\text { Gravidarum }\end{array}$} & \multirow[t]{2}{*}{ Jumlah } & \multirow[t]{2}{*}{$\begin{array}{c}P \\
\text { value }\end{array}$} \\
\hline & & \multicolumn{2}{|c|}{ Ya } & Tidak & & \\
\hline & & $\mathbf{n}$ & $\%$ & n $\%$ & $\%$ & \\
\hline 1. & Resiko tinggi & 36 & 52,9 & 3247,1 & $68 \quad 100$ & \\
\hline 2. & Resiko rendah & 10 & 20 & $\begin{array}{ll}40 & 80\end{array}$ & $\begin{array}{ll}50 & 100\end{array}$ & 0,001 \\
\hline & Jumlah & 46 & - & 72 & $118-$ & \\
\hline
\end{tabular}
responden dengan umur resiko tinggi yang mengalami hiperemesis gravidarum sebanyak 36 responden $(52,9 \%)$ dan umur resiko tinggi yang tidak hiperemesis gravidarum sebanyak 32 responden $(47,1 \%)$ dari 50 responden dengan umur resiko rendah yang mengalami hiperemesis gravidarum sebanyak 10 responden $(20 \%)$ dan umur resiko rendah yang tidak hiperemesis gravidarum sebanyak 40 responden (80\%).

Berdasarkan hasil uji statistik Chi-Square didapatkan $p$ value $=0,001$ lebih kecil dari nilai $\alpha$ $=0,05$ artinya ada hubungan bermakna antara umur dengan kejadian hiperemesis Gravidarum 
Jurnal Kebidanan :Jurnal Medical Science Ilmu Kesehatan Akademi Kebidanan Budi Mulia Palembang Volume.10 No.2, Desember 2020

\section{Hubungan antara Paritas dengan Kejadian Hiperemesis Gravidarum.}

Dilakukan Uji Statistik bivariat antara variabel dependen (kejadian Hiperemesi Gravidarum) dengan variabel independen (paritas). Hasil uji statistik dapat dilihat pada tabel 5 di bawah ini.

\section{Tabe1 5 Hubungan Antara Paritas dengan Kejadian Hiperemesis Gravidarum pada ibu Hamil di Klinik Budi MuliaMedika Palembang Tahun 2020}

\begin{tabular}{|c|c|c|c|c|c|c|c|}
\hline \multirow[t]{3}{*}{ No } & \multirow[t]{3}{*}{ Paritas } & \multicolumn{4}{|c|}{$\begin{array}{c}\text { Kejadian } \\
\text { Hiperemesis } \\
\text { Gravidarum }\end{array}$} & \multirow[t]{2}{*}{ Jumlah } & \multirow[t]{2}{*}{ P value } \\
\hline & & \multicolumn{2}{|c|}{$\mathbf{Y a}$} & \multicolumn{2}{|c|}{ Tidak } & & \\
\hline & & n & $\%$ & $\mathbf{n}$ & $\%$ & $\%$ & \multirow{4}{*}{0,001} \\
\hline 1. & Resiko tinggi & 37 & 64,9 & 20 & 35,1 & 57100,0 & \\
\hline 2. & Resiko rendah & 9 & 14,8 & 52 & 85,2 & 61100,0 & \\
\hline & Jumlah & 46 & - & 72 & - & 118 & \\
\hline
\end{tabular}

Berdasarkan tabel 5 dari 57 responden dengan paritas resiko tinggi yang mengalami hiperemesis gravidarum sebanyak 37 responden $(64,9 \%)$ dan paritas resiko tinggi yang tidak hiperemesis gravidarum sebanyak 20 responden $(35,1 \%)$ dan dari 61 responden dengan paritas resiko rendah yang mengalami hiperemesis gravidarum sebanyak 9 responden $(14,8 \%)$ dan paritas resiko rendah yang tidak hiperemesis gravidarum sebanyak 52 responden $(85,2 \%)$.

Berdasarkan hasil uji statistik Chi-Square didapatkan $p$ value $=0,001$ lebih kecil dari nilai $\alpha$ $=0,05$ artinya ada hubungan bermakna antara paritas dengan kejadian hiperemesis Gravidarum.

\section{PEMBAHASAN}

\section{Kejadian Hiperemesis Gravidarum}

Hiperemesis gravidarum adalah muntah yang terjadi sampai umur kehamilan 20 minggu. Muntah begitu hebat dimana segala apa yang dimakan dan diminum dimuntahkan sehingga mempengaruhi keadaan umum dan pekerjaan sehari-hari, berat badan menurun dan dehidrasi (Nugraha, 2010). Hasil analisis univariat menunjukan bahwa responden yang mengalami hiperemesis gravidarum sebanyak 46 orang $(38,9$ $\%)$ dan ibu yang tidak mengalami hiperemesis gravidarum sebanyak 72 orang $(61,1 \%)$. Pada penelitian ini jumlah ibu yang tidak mengalami hiperemesis gravidarum lebih banyak hal ini dimungkinkan karena beberapa factor diantaranya penanganan dan penerimaan kehamilan ibu dengan lebih baik sehingga memungkinkan ibu hamil untuk menerima perubahan pada saat hamil termasuk keadaan mual dan muntah dengan lebih baik sehingga tidak sampai menjadi hiperemesis gravidarum.

\section{Hubungan antara Umur Ibu dengan Kejadian Hiperemesis Gravidarum}

Dari hasil analisis bivariat responden dengan umur resiko tinggi lebih banyak $(57,6 \%)$, dibandingkan dengan responden umur resiko rendah $(42,4 \%)$. Responden dengan umur resiko tinggi yang mengalami hiperemesis gravidarum lebih banyak $(52,9 \%)$ dibandingkan dengan yang tidak hiperemesis gravidarum $(47,1 \%)$ dan responden dengan umur resiko rendah yang tidak mengalami hiperemesis gravidarum lebih banyak $(80 \%)$ dibandingkan dengan yang mengalami hiperemesis gravidarum (20\%).

Dari hasil uji statistik Chi-Square terdapat hubungan yang bermakna antara umur dengan kejadian hiperemesis gravidarum di Klinik Budi Mulia Medika Palembang tahun 2020 dimana diperoleh $p$ value $=0,001$ lebih kecil dari $\alpha=$ 0,05 sehingga hipotesa mengatakan ada hubungan antara umur dengan kejadian hiperemesis gravidarum terbukti secara statistik. Hal ini sesuai dengan penelitian yang dilakukan oleh Wahidudin (2007), hiperemesis gravidarum dibawah umur 20 tahun lebih disebabkan karena belum cukupnya kematangan fisik, mental dan fungsi sosial dari calon ibu. Hal ini mempengaruhi emosi ibu sehingga terjadi konflik mental yang membuat nafsu ibu kurang makan. Sedangkan hiperemesis gravidarum yang terjadi diatas umur 35 tahun juga tidak lepas dari faktor psikologis yang disebabkan karena tidak menginginkan kehamilannya lagi sehingga merasa tertekan dan menimbulkan stres. Hal ini yang memicu terjadinya mual dan muntah pada ibu.

\section{Hubungan anatara Paritas Ibu dengan Kejadian Hiperemesis Gravidarum}

Hasil analisis bivariat menunjukkan responden dengan paritas resiko tinggi yang mengalami hiperemesis gravidarum lebih banyak $(64,9 \%)$ dibandingkan yang tidak mengalami hiperemesis gravidarum $(35,1 \%)$ sedangkan pada responden dengan paritas resiko rendah jumlah ibu yang mengalami hiperemesis gravidarum ledih sedikit $(14,8 \%)$ Dari hasil uji statistik ChiSquare terdapat hubungan yang bermakna antara paritas dengan kejadian hiperemesis gravidarum di Klinik Budi Mulia Medika Palembang tahun 
Jurnal Kebidanan :Jurnal Medical Science Ilmu Kesehatan Akademi Kebidanan Budi Mulia Palembang Volume.10 No.2, Desember 2020

2020 dimana diperoleh $p$ value $=0,001$ lebih kecil dari $\alpha=0,05$ sehingga hipotesa yang mengatakan ada hubungan antara paritas dengan kejadian hiperemesis gravidarum terbukti secara statistik. Hal ini sejalan dengan teori Prawirohardjo (2008) bahwa mual dan muntah terjadi $60-80 \%$ pada kehamilan pertama (primigravida) dan 40-60\% wanita yang sudah pernah hamil lebih dari satu kali (multigravida). Jumlah kehamilan 2-3 (multi) merupakan paritas paling aman.

Berdasarkan penelitian Ridwan (2007) Hiperemesis Gravidarum lebih banyak terjadi pada ibu yang baru pertama kali hamil dibandingkan dengan ibu yang sudah mengalami kehamilan sebelumnya. Hal ini tidak terlepas oleh karena faktor psikologis yakni takut terhadap tanggung jawab sebagai ibu, ini dapat menyebabkan konflik mental yang dapat memperberat mual muntah pada saat kehamilan dan menjadi hiperemesis gravidarum.

\section{KESIMPULAN}

Berdasarkan hasil penelitian di Klinik Budi Mulia Medika Palembang Tahun 2020 yang berjudul hubungan antara umur dan paritas dengan kejadian Hiperemesis Gravidarum pada ibu Hamil di Klinik Budi Mulia Medika Palembang Tahun 2020 dengan sampel sebanyak 118 responden didapatkan hasil penelitian sebagai berikut : Ada hubungan yang bermakna antara umur dengan kejadian Hiperemesis Gravidarum di Klinik Budi Mulia Medika Palembang Tahun 2020 dengan $P$ value 0,001 . Ada hubungan yang bermakna antara paritas dengan kejadian Hiperemesis Gravidarum di Klinik Budi Mulia Medika Palembang Tahun 2020 dengan $P$ value 0,001 .

\section{SARAN}

\section{Bagi Bagi Petugas Kesehatan di Klinik} Budi Mulia Medika Palembang

Diharapkan hasil penelitian ini dapat dijadikan informasi untuk tenaga kesehatan di Klinik Budi Mulia Medika Palembang dalam memberikan penyuluhan dan konseling langsung kepada pasien yang menderita hiperemesis gravidarum dengan melihat factor resiko yang menjadi penyebab terjadinya hiperemesisgravidarum.

2. Bagi Peneliti Yang Akan Datang

Diharapkan dapat lebih menggali dan mengembangkan teori-teori tentang hiperemesis gravidarum dan menambah variabel yang diteliti seperti faktor kejiwaan dan penanganan stress yang berkaitan dengan faktor penyebab hiperemesis gravidarum.

\section{DAFTAR PUSTAKA}

Anwar, Indra NC. 2010. Kebidanan Kandungan. (http://www.klikdokter.com/ medisaz/read/2010/07/05/22/hiperemesisgravidarum.

Guyton A.C., Hall J.E. 2006. Buku Ajar. Fisiologi Kedokteran Edisi 11.Jakarta: EGC.

Hendra. 2010. Asuhan Keperawatan Pada Ibu Hamil dengan HEG. (http://kesehatan.myhendra.web.id/2010/0 8/asuhan-keperawatan-pada-ibu-hamildengan-hiperemesis-gravidarum.

Hidayat, A. Aziz Alimul. 2010. Metode Penelitian Kebidanan dan Teknik Analisis Data. Salemba Medika : Jakarta.

Himapid. 2009. Kematian Maternal. (http://himapid.blogspot.com.

Manuaba, Chandranita. 2008. Gawat Darurat Obstetri, Ginekologi dan Obstetri, Ginekologi Sosial Untuk Profesi Bidan. EGC : Jakarta.

Manuaba, Ida Bagus Gde, 2017. Ilmu Kebidanan, Penyakit Kandungan dan Keluarga Berencana, Jakarta : Buku Kedoteran

Notoatmodjo, Soekidjo. 2018. Metodologi Penelitian Kesehatan. Rineka Cipta : Jakarta.

Nugroho, Taufan. 2010. Kasus Emergency Kebidanan Untuk Kebidanan dan Keperawatan. Nuha Medika : Yogyakarta.

Prawirohardjo, Sarwono, 2018. Ilmu Kebidanan : PT. Bina Pustaka. Jakarta.

Proverawati Kusumawati. 2009. Buku Ajar Gizi untuk Kebidanan. Nuha Medika.Yogyakarta.

Ridwan. 2007. Hiperemesis Gravidarum. (http://razak2007.blogspot.com.

Saifuddin, Abdul Bari. 2009. Ilmu Kebidanan (Kematian $\mathrm{Ibu}$ dan Perinatal). Bina Pustaka. Jakarta.

Wiknjosastro, Hanifa, 2008. Ilmu Kandungan. Jakarta : Bina Pustaka. 
